\title{
Composition and diversity of ichthyofauna in La Viña reservoir (Córdoba, Argentina)
}

\author{
Mancini, M. ${ }^{\text {a* }}$,Haro, . $^{\text {b }}$, Bucco, $C^{\text {c }}$, Salinas, $V^{\mathrm{a}}$ and Miquelarena, $A .^{\mathrm{d}}$ \\ ${ }^{a}$ Acuicultura, Facultad de Agronomía y Veterinaria, Universidad Nacional de Río Cuarto - UNRC, \\ Ruta Nac. 36, Km 601, CP 5800, Río Cuarto, Argentina \\ bCátedra de Diversidad Animal II y Museo de Zoología, Universidad Nacional de Córdoba - UNC, \\ Vélez Sársfield, 299, CP 5000, Córdoba, Argentina \\ 'Guardafauna de la provincia de Córdoba, Argentina \\ ${ }^{\mathrm{d}}$ División Zoología Vertebrados, Museo de La Plata, Universidad Nacional de La Plata - UNLP, \\ Paseo del Bosque, s/n, CP 1900, La Plata, Argentina \\ *e-mail: mmancini@ayv.unrc.edu.ar
}

Received June 15, 2007 - Accepted July 11, 2007 - Distributed February 28, 2009

(With 4 figures)

\begin{abstract}
Several dams have been built in central and north Argentina. There are more than 20 reservoirs in Córdoba province, with a total estimated surface area of around 15,000 ha. Although construction of dams continues, some aspects about the richness, abundance and diversity of ichthyofauna in many of these environments are unknown, which prevents adequate management of fish resources. The goal of this work was to evaluate specific richness and diversity of ichthyofauna in La Viña reservoir ( $31^{\circ} 47^{\prime} \mathrm{S}$ and $65^{\circ} 01^{\prime} \mathrm{W}, 1,050 \mathrm{ha}, 846 \mathrm{~m}$ asl), one of the major reservoirs in Córdoba. Fifteen seasonal samplings were made in 1999-2002 using trawl nets and gillnets. A total of 3,242 specimens belonging to 7 species distributed in 5 orders and 5 families were caught. The tetra Astyanax eigenmanniorum (52.9\%) and the silverside Odontesthes bonariensis $(29.3 \%$ ) were the most abundant species; the latter is the main target species for lake fishing and had greatest biomass $(63.8 \%)$. Average diversity for all samples was $\mathrm{H}_{\mathrm{T}}{ }_{\mathrm{T}} 1.63(95 \%$ confidence interval 1.49 to 1.77). Shannon-Wiener and Simpson diversity indexes values were generally intermediate. Specific richness of La Viña reservoir was moderate compared with other impoundments in central and north Argentina.
\end{abstract}

Keywords: freshwater fish, diversity, reservoirs, Argentina.

\section{Composição e diversidade da ictiofauna do reservatório La Viña (Córdoba, Argentina)}

\section{Resumo}

$\mathrm{Na}$ área central e norte da Argentina há uma importante quantidade de represas. Na província de Córdoba, existem, na atualidade, mais de 20 reservatórios que ocupam uma superfície aproximada de 15.000 ha. Embora a construção de represas continue em uma grande quantidade de ambientes, não se conhecem alguns aspectos da riqueza, abundância e diversidade da ictiofauna, dificultando a gestão e manejo dos recursos pesqueiros. O objetivo do trabalho foi avaliar a riqueza específica e a diversidade da ictiofauna do reservatório La Viña ( $31^{\circ} 47^{\prime} \mathrm{S}$ e $65^{\circ} 01^{\prime} \mathrm{W}, 1.050 \mathrm{ha}, 846 \mathrm{msnm}$ ), um dos mais importantes de Córdoba. No período entre 1999-2002, realizaram-se 15 amostragens estacionais, utilizando-se redes de arrasto e de espera. Coletaram-se 3.242 indivíduos de 7 espécies distribuídas em 5 ordens e 5 famílias. Em função do número total de espécies, as de maior abundância foram lambari Astyanax eigenmanniorum $(52,9 \%)$ e peixe-rei Odontesthes bonariensis $(29,3 \%)$, sendo esta última espécie o objetivo da pescaria do lago e a que alcançou a maior biomassa $(63,8 \%)$. Considerando o total da amostragem, a diversidade média foi de $\mathrm{H}^{\prime}{ }_{\mathrm{T}=}{ }^{1,63}$, com um intervalo de confiança (95\%) de 1,49 a 1,77. No geral, os índices de diversidade de Shannon-Wiener e Simpson foram médios. Comparando com outros reservatórios da área central e norte da Argentina, a riqueza específica do reservatório La Viña é moderada.

Palavras-chave: peixes, diversidade, reservatórios, Argentina. 


\section{Introduction}

Reservoirs are artificial lakes of various sizes created by the construction of dams for diverse purposes. The number of dams has increased during recent years, and this situation has contributed to the increase in the volume of lentic environments on the planet during the $20^{\text {th }}$ century, one of the greatest man-made modifications to hydrological basins (Cole, 1988; Locascio de Mitrovich et al., 1997).

Several dams have been built in central and north Argentina. The discrepancy between natural precipitation regimes and the human demand for water was one of the factors that prompted Córdoba to be among the first provinces to regulate hydrological resources in Argentina. This province has more than 20 impoundments, comprising an approximate surface area of 15,000 ha (Di.P.A.S., 2000). Some of the major uses are energy generation, buffering and control of irregular river flows, water supply, recreation and fishing, among others. Fish resources are extremely valuable as sport fishing items, general environmental indicators, as well as fish captured for both consumption and recreation. In addition, the biological conditions of a fish community are sensitive indicators of the "health" of an aquatic ecosystem and reflect environmental conditions of the water body (Smith and Berrella, 2000; López et al., 2001; Schulz and Martins-Junior, 2001).

Given that fish species play relevant ecosystemic and social roles, fish resources should be approached by the different parties that exploit the system from a general perspective of sustainable use. Although several works on various ichthyological aspects have been carried out in Córdoba province (Haro and Bistoni, 1996), there are still numerous environments whose faunal richness remains undescribed. This lack of knowledge hinders a proper and sustainable management of these resources. The goal of this work was to assess the composition and diversity of ichthyofauna in La Viña reservoir.

\section{Materials and Methods}

\subsection{Study area}

La Viña reservoir $\left(31^{\circ} 47^{\prime} \mathrm{S}\right.$ and $65^{\circ} 01^{\prime} \mathrm{W}$ ), also known as Ingeniero Medina Allende dam, is located in Traslasierra valley, Córdoba province, west of the Sierras Grandes (Argentina). The homonymous compensating dam is located downstream from La Viña (Figure 1). The La Viña reservoir is formed by a box-shaped basin with high-slope margins, with a surface area of 1,050 ha (at maximum reservoir level) and a volumetric capacity of $242 \mathrm{hm}^{3}$; its altitude is $846 \mathrm{~m}$ asl (Di.P.A.S., 2000). The impoundment is located within an endorrheic basin, and its main water supply is provided by Los Sauces river. The steeply-inclined recharge area comprises $878 \mathrm{~km}^{2}$, and its potential irrigation capacity is 22,000 ha.

La Viña reservoir represents an important hydrological store destined to the production of energy and

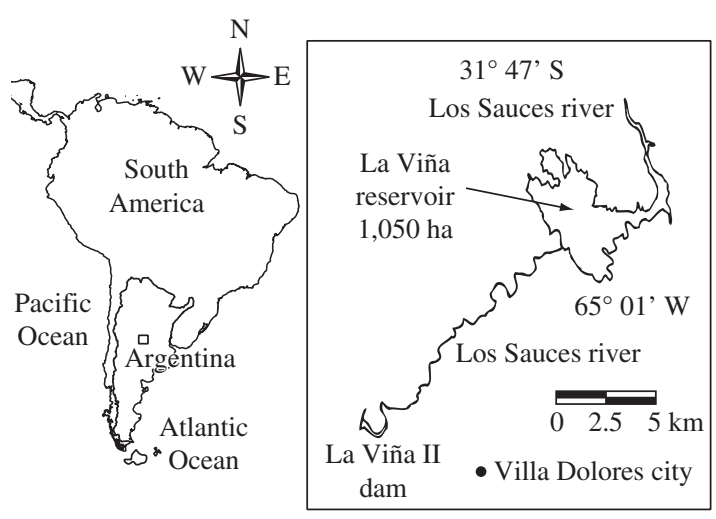

Figure 1. Geographical location of La Viña reservoir.

a drinkable water supply, as well as being a significant touristic asset. It is one of the most visited sites in Córdoba province for recreational fishing of the silverside Odontesthes bonariensis, a species that was first introduced in 1944 using specimens from the Río Tercero reservoir. Odontesthes bonariensis is the main target species for sport fisheries in central Argentina (Baigún and Delfino, 1994).

The climate in the area is mild, dry semi-arid, with precipitation deficit during most of the year, and mean annual temperatures varying from mild to warm. Monthly minimum and maximum temperatures are 10.3 and $25.0{ }^{\circ} \mathrm{C}$ and occur in July and January respectively (Servicio Meteorológico Nacional, 1992). Mean annual precipitation is $650 \mathrm{~mm}$ (Di.P.A.S., 2000).

In recent years this reservoir has been classified as eutrophic, especially during the warmer months, with occurrence of dinoflagellate florations, low water transparency and occasional massive fish mortality (Rodriguez et al., 2005).

\subsection{Study and analysis of the ichthyofauna}

A total of 15 seasonal samplings were carried out between 1999 and 2002, with reservoir levels always above $95 \mathrm{~m}$. Active and passive fishing methods were used (Scasso, 1999):

a) Trawl nets dragged toward the coast, $20 \mathrm{~m}$ long, with $3.5 \mathrm{~m}$ codend (mesh size $5 \mathrm{~mm}$ ).

b) Three multifilament nylon floating gillnet sets for experimental fishing, with mesh sizes 15, 19, 22, $25,30,33,38$ and $40 \mathrm{~mm}$ from knot to knot (total length $68.75 \mathrm{~m}$ ). These nets were put in place at sunset-night and collected the following morning. A minimum of two gillnet sets, placed in parallel and perpendicularly to the coast, were used each night.

The specimens were identified according to Ringuelet et al. (1967) and Fernández (1994), and the systematic scheme follows López et al. (2003). For biomass measurements, all specimens were weighed to $0.1 \mathrm{~g}$ accuracy. 
Alpha diversity was evaluated by means of the Shannon-Wiener index: $\mathrm{H}=-\Sigma\left(\mathrm{p}_{\mathrm{i}}\right)\left(\log _{2} \mathrm{p}_{\mathrm{i}}\right)$, where pi is the proportion of the total sample corresponding to the i species (Krebs, 1995). The following scale was used for interpretation of results: 0 to 1 bits - low diversity; 1-2 bits - moderate diversity; and 2 or more bits - high diversity. The following indexes were also used:

- Evenness index (Pielou's index), $\mathrm{E}=\mathrm{H} / \log _{2} \mathrm{~S}$, where $\mathrm{S}$ is the number of species in the sample. The scale used for interpretation was 0 to 0.5 - low evenness; 0.5 to 0.6 - intermediate evenness and 0.6 to $1-$ high evenness.

- Simpson's Index $S=1-\Sigma\left(p_{\mathrm{i}}\right)^{2}$. The scale for interpretation was 0 to 0.5 - low diversity; 0.5 to 0.6 - intermediate diversity, and 0.6 to 1 - high diversity (Odum, 1998; Moreno, 2001).

Possible relationship between diversity indexes values and sample size was assessed by means of Spearman's correlation coefficient. Lastly, total diversity $\left(\mathrm{H}_{\mathrm{T}}{ }_{\mathrm{T}}\right)$ and its variability were calculated following Bolaños (2000), by jackknifing, using the estimated standard error to derive a 95\% confidence interval (Godínez-Dominguez and González-Sansón, 1999).

Similarity with other 7 reservoirs from central-north Argentina was evaluated by means of the Jaccard and Sorensen indexes, calculated from presence/absence data for fish species (Magurran, 1989).

\section{Results}

A total of 3,242 specimens belonging to 7 species in 5 orders and 5 families were collected (Table 1).
The most abundant species was the tetra Astyanax eigenmanniorum (52.9\%), the second most abundant was the silverside Odontesthes bonariensis (29.3\%) and the third most abundant was the pike characin Oligosarcus jenynsii $(13,6 \%)$. O. bonariensis was the most important in terms of biomass, with $63.8 \%$, followed by A. eigenmanniorum with $26.0 \%$ (Figure 2). A total of 952 silversides were caught, 36.9 of which were caught by trawl net and $63.1 \%$ by gillnet.

Astyanax eigenmanniorum was the most abundant species in trawl net captures $(65.8 \%)$ while $O$. bonariensis was the most abundant capture when using gill net (65.3\%). Figures 3 and 4 show the results by fishing method in percentages.

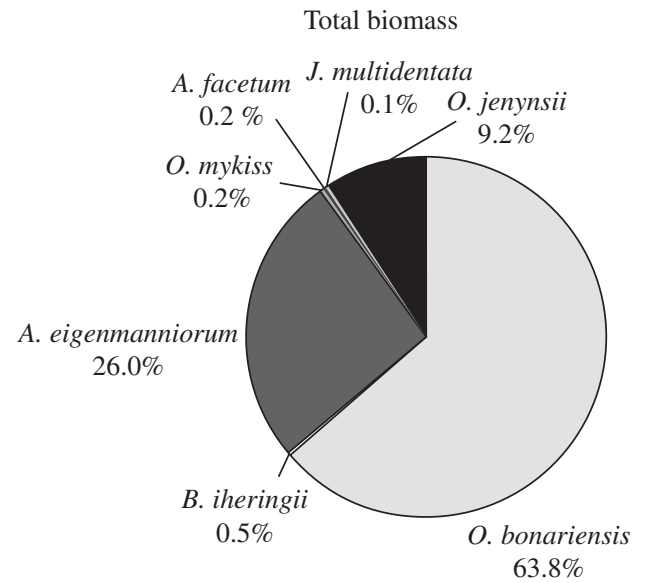

Figure 2. Relative fish abundance ( $\%$ of total biomass) of La Viña reservoir.

Table 1. Species collected in La Viña reservoir.

\begin{tabular}{cc}
\hline \multicolumn{1}{c}{ Order/Family/Species } & Common name \\
\hline Characiformes & \\
CHARACIDAE & \\
Subfamily Tetragonopterinae & Mojarra, chato \\
Astyanax eigenmanniorum (Cope, 1984) & Mojarra, mojarrita \\
Bryconamericus iheringii (Boulenger, 1887) & Dientudo, mojarrón \\
Oligosarcus jenynsii (Günther, 1864) & \\
Perciformes & \\
CICHLIDAE & Chanchita, palometa \\
Australoheros facetum (Jenyns, 1842) & \\
Cyprinodontiformes & Madrecita, orillero \\
ANABLEPIDAE & \\
Jenynsia multidentata (Jenyns, 1842) & \\
Atheriniformes & Pejerrey, flecha de plata \\
ATHERINOPSIDAE & \\
Odontesthes bonariensis (Valenciennes, 1835) &
\end{tabular}




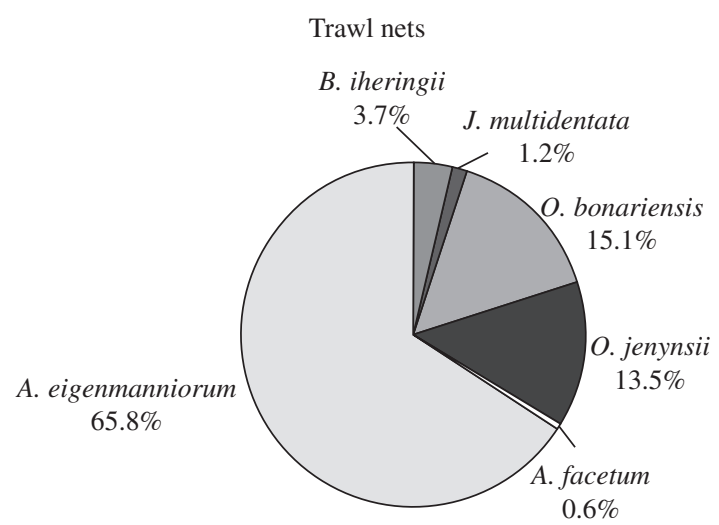

Figure 3. Relative fish abundance (\% of the number) in La Viña reservoir (trawl nets).

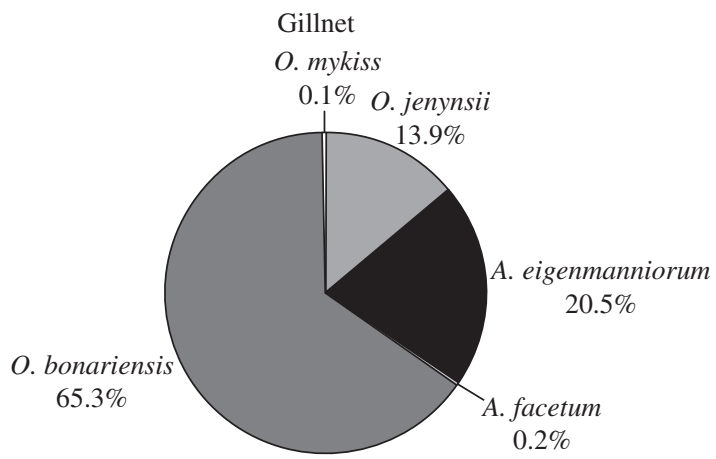

Figure 4. Relative fish abundance (\% of the number) in La Viña reservoir (gillnet).

Mean diversity for all samples was $\mathrm{H}_{\mathrm{T}}{ }^{\prime}=1.63$ $(\mathrm{n}=15)$, with $95 \%$ confidence interval ranging from 1.49 to 1.77 . The values of the Shannon-Wiener diversity index were always low to moderate, never above 1.95 bits. However, the values of Simpson's index were high in some cases, ranging from 0.12 to 0.72 . No significant correlation was detected between the values of Shannon-Wiener index and sample size (Spearman, $\left.\mathrm{r}_{\mathrm{s}}=0.093 ; \mathrm{n}=15 ; \mathrm{P}=0.74\right)$, or between the latter and Simpson's index (Spearman, $\mathrm{r}_{\mathrm{s}}=0.25 ; \mathrm{n}=15 ; \mathrm{P}=0.36$ ). These results indicate that the diversity values observed are not an artifact derived from the number of individuals captured. The values of Pielou's equity index varied in an ample range (Table 2).

According to Jaccard's and Sorensen's indexes, La Viña reservoir is most similar to the Olta (La Rioja) and Río Tercero (Córdoba) impoundments, with 4 and 7 common species, respectively (Table 3 ).

\section{Discussion and Conclusions}

The ichthyofaunal composition of Argentina has been increased recently (Menni, 2004; López et al., 2006). Relatively intense studies have been carried out in lakes, lagoons and artificial reservoirs in Córdoba, which is the second most important province in terms of number of
Table 2. Diversity indexes of the ichthyofauna of La Viña reservoir. Shannon-Wiener $(\mathrm{H})$, Simpson $(\mathrm{S})$ and evenness (E).

\begin{tabular}{llcrccc}
\hline Sampling & Season & $\begin{array}{c}\text { Specific } \\
\text { richness }\end{array}$ & n & H & S & E \\
\hline 1 & Summer & 5 & 111 & 1.95 & 0.72 & 0.84 \\
2 & Winter & 6 & 29 & 1.38 & 0.45 & 0.59 \\
3 & Spring & 4 & 168 & 1.31 & 0.51 & 0.66 \\
4 & Winter & 6 & 173 & 0.47 & 0.12 & 0.18 \\
5 & Spring & 4 & 454 & 1.39 & 0.57 & 0.70 \\
6 & Spring & 5 & 288 & 1.19 & 0.44 & 0.51 \\
7 & Summer & 5 & 211 & 1.45 & 0.58 & 0.62 \\
8 & Autumn & 4 & 103 & 1.22 & 0.43 & 0.61 \\
9 & Winter & 4 & 76 & 1.46 & 0.57 & 0.73 \\
10 & Winter & 3 & 92 & 0.60 & 0.20 & 0.38 \\
11 & Spring & 5 & 330 & 1.52 & 0.59 & 0.66 \\
12 & Summer & 5 & 446 & 1.11 & 0.37 & 0.37 \\
13 & Summer & 6 & 449 & 1.78 & 0.64 & 0.69 \\
14 & Autumn & 5 & 64 & 1.51 & 0.55 & 0.65 \\
15 & Autumn & 6 & 248 & 1.56 & 0.60 & 0.60 \\
\hline
\end{tabular}

species, with a total of 47 to 50 species cited (Haro and Bistoni, 1996; López et al., 1996). The majority of these works comprise information about fisheries biology, distribution, diseases and conservation (Freyre et al., 1983; Menni et al., 1984; Mancini et al., 2000; Orlandini et al., 2001; among others), but the amount of research focused on ecological issues and the consequences of anthropogenic influence is limited (López et al., 1996). These latter authors noted the important deficit of ichthyological studies in environments subject to high anthropogenic impact, such as the impoundments in central Argentina.

In contrast to natural lakes, reservoirs do not host a balanced fish community produced by prolongued coevolutionary relationships between species and their environment. Although the ichthyofaunal assemblage is originated from the impoundment of rivers, many riverine species are not able to adapt to the new conditions and may disappear (Quirós, 2003). The number of species present in La Viña reservoir was higher than that recorded for Sumampa reservoir (Silverio et al., 2004), similar to the one described for San Roque reservoir (Gordillo, 1986) and quite lower than those recorded in the impoundments of Río Tercero (Freyre et al., 1983), Piedras Moras (Mancini et al., 2001), La Quebrada (Kutel and Bistoni, 2000), Cabra Corral (Barrientos and Baigún, 2005), El Tunal (Villagra et al., 2005), El Cadillal and Río Hondo (Butí, 1995; Locascio de Mitrovich et al., 1997), all of these situated in central-north Argentina. None of the species recorded was present in all of these environments.

Among the fish species shared by these reservoirs, the silverside is the most common, occurring in $87.5 \%$ of them. $O$. jenynsii occupies the second place, occur- 
Table 3. Similarity with 7 other impoundments from central-north Argentina. (1): Barrientos and Baigún, 2005; (2): Butí, 1995; (3): Silverio et al., 2004; (4): Kutel and Bistoni, 2000; (5): Freyre et al., 1983; (6): Mancini pers. com.

\begin{tabular}{|c|c|c|c|c|c|c|}
\hline Reservoir & Location & Province & $\begin{array}{l}\text { Specific } \\
\text { richness }\end{array}$ & $\begin{array}{l}\text { Species in } \\
\text { common }\end{array}$ & $\begin{array}{c}\text { Jaccard } \\
\text { index }\end{array}$ & $\begin{array}{c}\text { Sorensen } \\
\text { index }\end{array}$ \\
\hline Cabra Corral (1) & $25^{\circ} 08^{\prime} \mathrm{S}$ and $65^{\circ} 20^{\prime} \mathrm{W}$ & Salta & 9 & 2 & 0.14 & 0.25 \\
\hline El Cadillal (2) & $26^{\circ} 40^{\prime} \mathrm{S}$ and $65^{\circ} 07^{\prime} \mathrm{W}$ & Tucumán & 11 & 4 & 0.28 & 0.44 \\
\hline Sumampa (3) & $28^{\circ} 01^{\prime} \mathrm{S}$ and $65^{\circ} 34^{\prime} \mathrm{W}$ & Catamarca & 3 & 3 & 0.42 & 0.60 \\
\hline La Quebrada (4) & $31^{\circ} 14^{\prime} \mathrm{S}$ and $64^{\circ} 20^{\prime} \mathrm{W}$ & Córdoba & 12 & 5 & 0.35 & 0.52 \\
\hline Río Tercero (5) & $32^{\circ} 10^{\prime} \mathrm{S}$ and $64^{\circ} 23^{\prime} \mathrm{W}$ & Córdoba & 13 & 7 & 0.53 & 0.70 \\
\hline Piedras Moras (6) & $32^{\circ} 12^{\prime} \mathrm{S}$ and $64^{\circ} 19^{\prime} \mathrm{W}$ & Córdoba & 10 & 5 & 0.41 & 0.58 \\
\hline Olta (6) & $30^{\circ} 38^{\prime} \mathrm{S}$ and $66^{\circ} 16^{\prime} \mathrm{W}$ & La Rioja & 4 & 4 & 0.57 & 0.72 \\
\hline
\end{tabular}

ring in $75.0 \%$ of the reservoirs analyzed. With the exception of the La Quebrada reservoir, the silverside is present in the ichthyofauna of all the other waterbodies analyzed to date, probably as a result of the large-scale introduction plans that were historically carried out in Argentina to promote recreational fishing of this species (Berasain et al., 1999), to the point that it has become the fish species with greatest sport and commercial acceptance in central-north Argentina (Grosman and Mancini, 2001). With respect to A. eigenmanniorum, the most abundant species in La Viña reservoir, our results agree with the statement by Menni et al. (1996) that it is the most eurytopic among 16 species occurring in many Argentinian habitats.

The values of Simpson's index were generally higher than those of Shannon Wiener index, perhaps due to the differential sensitivity of these indexes to differences in the abundance of rare and common species (Magurran, 1989). One explanation for the species richness found in La Viña reservoir could be the complete lack of hydrophytes that are common in other similar sites (Kutel and Bistoni, 2000). The ecological interactions between fish and macrophytic communities have been studied throughout the world. The presence of vegetation is generally associated with more diversity of species, because plants create new microhabitats that supply resources such as food, substrate for spawning, refuge and protection from predators (Smith and Barrella, 2000; Casatti et al., 2003; Whitfield and Paterson, 2003). La Viña reservoir's relief, is abrupt in general, with rocky substrate and low water transparency. These factors would preclude colonization by aquatic plants. Only a very small area was observed to be covered by the marsh macrophyte Alternanthera sp. Another possible factor associated with species richness would be the endorheic nature of this basin and the lack of connections with the "Paranense" basin, which is the source of the majority of the species. Low species richness is one of the characteristic traits of arheic systems.

The analysis of the fish fauna of superficial waters in Córdoba and San Luis provinces is especially relevant due to the different geomorphological, biogeographical and biotic characteristics of these areas. La Viña dam was built with the purpose of holding the drainage wa- ters of the endorheic system formed by the Panaholma and Mina Clavero rivers (Ringuelet, 1975). The species captured at La Viña, with the exception of $O$. bonariensis and Oncorhynchus mykiss, are also among the 9 species recorded in various aquatic (mainly lotic) environments of the western slopes of the Sierras Grandes (Menni et al., 1984; Miquelarena and Menni, 1992; Menni, 2004). According to Bistoni and Hued (2002), O. mykiss is characteristic of upstream cold waters in lotic environments of Córdoba province. This would explain its low abundance in La Viña reservoir probably due to the proximity of commercial fish farms dedicated to intensive production of this salmonid. The absence of the pencil catfish Trichomycterus corduvensis, an inhabitant of cold fast-flowing mountain streams (Ringuelet et al., 1967), and whose capture has been recorded in the upper basin (Haro and Bistoni, 2007) is a similar case.

In Los Sauces river, a few meters away from La Viña reservoir and near the wall of La Viña compensating dam $\left(31^{\circ} 52^{\prime} \mathrm{S}\right.$ and $65^{\circ} 10^{\prime} \mathrm{W}$ ), we recorded the capture by sport fishermen of several specimens of the smallmouth perch Percichthys trucha, a species transplanted into Córdoba (Bonetto et al., 1976; Haro and Bistoni, 2007), but not yet introduced into La Viña dam basin (Ringuelet, 1975).

In contrast with the situation in other reservoirs in Córdoba province, such as San Roque, Los Molinos and Río Tercero, no specimens of the common carp Cyprinus carpio were collected in La Viña. This species, currently widespread throughout the world, represents an ecological threat due to its high prolificity, marked rusticity and its ability to alter ecosystem characteristics, in addition to its feeding habits (Colautti and Remes Lenicov, 2001; Mehner et al., 2004; Smith, 2004). Nervertheless, there are at present verbal reports from sport fishermen mentioning the presence of large individuals of this species. The ornamental species Carassius auratus, which was previously reported for this location by Haro and Bistoni (1996), was not captured either. The great abundance of $O$. jenynsii and A. eigenmanniorum specimens might exert a negative effect on $O$. bonariensis, the most important fishing species for this lake; the first $(O$. jenynsii) because of its intense predation on silverside eggs and 
juveniles (Haro and Gutierrez, 1985; Aquino, 1993) and the second (A. eigenmanniorum) because of its possible consumption of silverside eggs (Gutierrez et al., 1983).

The fish fauna of La Viña reservoir is moderately diverse. A. eigenmanniorum is the most abundant species. The target species for lake fishing, $O$. bonariensis, is second in number of specimens, and first in biomass. The occurrence of $C$. carpio, after this study was finished, represents a new confirmation of the ubiquitous nature of its habits. The fish richness of La Viña reservoir is moderate compared to other impoundments in central and north Argentina.

Acknowledgements - We thank the authorities of Club APA La Viña, and the licensees of Club APA II, Daniel and María; Elena Fernádez; the Secretaría de Ciencia y Técnica of Universidad Nacional de Río Cuarto and Roberto C. Menni (MLP) for critical reading of the manuscript.

\section{References}

AQUINO, A., 1993. Hábitos alimentarios de Oligosarcus jenynsii (Pisces, Characidae) en el embalse El Cadillal (Tucumán, Argentina). Acta zool. lilloana, vol. XLII, no. 2, p. 267-277.

BAIGÚN, C. and DELFINO, R., 1994. Relación entre factores ambientales y biomasa relativa de pejerrey en lagos y embalses templado-cálidos de la Argentina. Acta Biol. Venez., vol. 15, no. 2, p. 47-57.

BARRIENTOS, J. and BAIGÚN, C., 2005. Embalses como ejemplos de sistemas de uso múltiple con importancia socioeconómica: la pesquería recreativa y deportiva del embalse Cabra Corral, Salta, Argentina. In: IV Taller Internacional sobre enfoques regionales para el desarrollo y gestión de embalses en la cuenca del Plata. Salto Grande, Argentina-Uruguay. (CDRom).

BERASAIN, G., VELASCO, C. and CHICLANA, M., 1999. Historia de la piscicultura del pejerrey en Chascomús, 17791999. In I Jornadas de Historia de Chascomús, Chascomús, Argentina. $20 \mathrm{p}$.

BISTONI, M.. and HUED, A., 2002. Patterns of fishs species richness in rivers of the central region of Argentina. Braz. J. Biol. $=$ Rev. Bras. Biol., vol. 62, no. 4b, p. 753-764.

BOLAÑOS, F., 2000. Diversidad y similitud. Laboratorio de Ecología General (B-305). Costa Rica: Universidad de Costa Rica, Escuela de Biología. 10 p.

BONETTO, A., DI PERSIA, D., MAGLIARESI, R. and CORIGLIANO, M., 1976. Caracteres limnológicos de algunos lagos eutróficos de embalses de la región central de Argentina. Ecosur, vol. 3, no. 5, p. 47-120.

BUTÍ, C., 1995. Ictiofauna del embalse C. Gelsi (El Cadillal) y sus tributarios, provincia de Tucumán, República Argentina. Acta zool. lilloana, vol. 43, no. 1, p. 207-213.

CASATTI, I., MENDES, H. and FERREIRA, K., 2003. Aquatic macrophytes as feeding site for small fishes in the Rosana reservoir, Paranapanema river, souteastern Brazil. Braz. J. Biol. $=$ Rev. Bras. Biol., vol. 63, no. 2, p. 213-222.

COLAUTTI, D. and REMES LENICOV, M., 2001. Alimentación de la carpa (Cyprinus carpio Linnaeus 1758) en la laguna de
Lobos, provincia de Buenos Aires, Argentina. Ecol. Austral, vol. 11, p. 69-78.

COLE, G., 1988. Manual de Limnología. Argentina: Hemisferio Sur. 405 p.

DIPAS., 2000. Dirección Provincial de Agua y Saneamiento. Min. de Obras Públicas, Sec. de Obras Públicas. Córdoba, Argentina: Gob. de Córdoba. 44 p.

FERNÁNDEZ, L., 1994. Claves para la identificación de los peces de la provincia de Tucumán (Argentina). Tucumán: Fundación Miguel Lillo. 28 p. (Miscelanea 97).

FREYRE, L., PROTOGINO, L. and IWASZKIW, J., 1983. Demografía del pejerrey Basilichthys bonariensis bonariensis en el embalse Río Tercero, Córdoba. Descripción de las artes de pesca. Biol. Acuát., vol. 4, p. 1-39.

GODÍNEZ-DOMINGUEZ, E. and GONZÁLEZ-SANSÓN, G., 1999. Diversidad de macroinvertebrados de fondos blandos de la plataforma continental de Jalisco y Colima, México. Cienc. Mar., vol. 25, no. 4, p. 609-627.

GORDILLO, S., 1986. Estudio del crecimiento de pejerrey Basilichthys bonariensis a partir de sus otolitos. Argentina: Universidad Nacional de Córdoba. 22 p.

GROSMAN, F. and MANCINI, M., 2001. Alcances socioeconómicos de la pesca deportiva de pejerrey (Odontesthes bonariensis). Real. Econ., vol. 184, p. 106-121.

GUTIERREZ, M., BARLA, M. and GIRAUDO, L., 1983. Alimentación de la población costera de Astyanax eigenmanniorum (Cope) (Pisces, Characiformes) del lago San Roque. Rev. Univ. Nac. Río Cuarto, vol. 3, n 1, p. 131-141.

HARO, J.G. and BISTONI, M., 1996. Ictiofauna de la provincia de Córdoba. In DITada, I. and BUCHER, E. (Eds.). Biodiversidad de la provincia de Córdoba. Argentina: Universidad Nacional de Río Cuarto. Fauna, vol. I, p. 169-190.

HARO, JG. and BISTONI, M. 2007. Peces de Córdoba. Argentina: Editorial Universidad Nacional de Córdoba. 246 p.

HARO, JG. and GUTIERREZ, M., 1985. Alimentación de Oligosarcus jenynsii (Günther) (Pisces, Characidae) en el lago San Roque (Córdoba, Argentina). Rev. Asoc. Cs. Nat. del Lit., vol. 16, no. 2, p. 227-235.

KREBS, C., 1995. Ecología. Estudio de la distribución y la abundancia. México: Ed. Harla. 753 p.

KUTEL, C. and BISTONI, M., 2000. Ictiofauna del dique La Quebrada (Córdoba, Argentina). Nat. Neotrop., vol. 31, no. 1-2, p. 11-16.

LOCASCIO De MITROVICH, C., VILLAGRA De GAMUNDI, A., TRACANNA, B., SEELIGMANN, C. and BUTI, C., 1997. Situación actual de la problemática limnológica de los embalses de la provincia de Tucumán (Argentina). Lilloa, vol. 39, no. 1, p. 81-93.

LÓPEZ, H., PROTOGINO, L. and AQUINO, A., 1996. Ictiología continental de la Argentina: Santiago del Estero, Catamarca, Córdoba, San Luis, La Pampa y Buenos Aires. Aquatec, vol. 3, p. 1-14.

LÓPEZ, H., BAIGÚN, C., IWASZKIW, J., DELFINO, R. and PADIN, O., 2001. La cuenca del Salado: uso y posibilidades de sus recursos pesqueros. La Plata, Argentina: Ed. de la Universidad de La Plata. 76 p. 
LÓPEZ, H., MIQUELARENA, A. and MENNI, R., 2003. Lista comentada de los peces continentales de la Argentina. $\mathrm{La}$ Plata, Buenos Aires: PublicArt. 87 p. (ProBiotA Serie Técnica y Didáctica $n^{\circ} 5$ ).

LÓPEZ, H., MENNI, R., FERRIZ, R., PONTE GÓMEZ, J. and CUELLO, M., 2006. Bibliografía de los peces continentales de la Argentina. ProBiota Serie Técnica y Didáctica n ${ }^{\circ}$. La Plata, Buenos Aires: FCNyM, UNLP. 171 p.

MAGURRAN, A., 1989. Diversidad ecológica y su medición. España: Ed. Vedia. 200 p.

MANCINI, M., LARRIESTRA, A. and SANCHEZ, J., 2000. Estudio ictiopatológico en poblaciones silvestres de la región centro-sur de la provincia de Córdoba, Argentina. Rev. Med. Vet. (B. Aires), vol. 81, no. 2, p. 104-108.

MANCINI, M., RODRIGUEZ, C., PROSPERI, C. and FINOLA, M., 2001. Evaluación de las interacciones tróficas del embalse Piedras Moras (Córdoba). In I Reunión Binacional de Ecología, Bariloche, Argentina.

MEHNER, T., ARLINGHAUS, R., BERG, S., JACOBSEN, L., KASPRZAK, P., KOSCHEL, R., SCHULZE, T., SKOV, C., WOLTER, C. and WYSUJACK, K., 2004. How to link biomanipulation and sustainble fisheries management: a stepby-step guideline for lakes ot the European temperate zone. Fish. Man. Ecol., vol. 11, p. 261-275.

MENNI, R., 2004. Peces y ambiente en de la Argentina continental. Monografía ${ }^{\circ}$ 5. Buenos Aires: Museo Argentino de Ciencias Naturales. 316 p.

MENNI, R.,LÓPEZ,H., CASCIOTTA, J. and MIQUELARENA, A., 1984. Ictiología de áreas serranas de Córdoba y San Luis (Argentina). Biol. Acuát., vol. 5, p. 1-63.

MENNI, R., GÓMEZ, S. and LÓPEZ ARMENGOL, F., 1996. Subtle relationships: freshwater fishes and water chemistry in southern South America. Hydrobiologia, vol. 328, p. 173-197.

MIQUELARENA, A. and MENNI, R., 1992. Presencia de Oligosarcus jenynsii en el oeste de Córdoba. Neotropica, vol. 38, no. 100 , p. 154.

MORENO, C., 2001. Métodos para medir la biodiversidad. Zaragoza. 84 p. (M6T-Manuales y Tesis SEA).

ODUM, E., 1998. Ecología. El vínculo entre las ciencias naturales y sociales. México: Compañía Editorial Continental. $295 \mathrm{p}$.

ORLANDINI, S., AÚN, L. and MARTORI, R., 2001. Estado de conservación de la ictiofauna de las sierras pampeanas de la provincia de Córdoba, Argentina. Bol. Soc. Biol. Concepción, Chile vol. 72, p. 91-103.
QUIRÓS, R., 2003. Principios de ordenación pesquera responsable en embalses con referencia a aquellos de América Latina. El Salvador: COPESCAl/FishCode/FAO. 12 p.

RINGUELET, R., 1975. Zoogeografía y ecología de los peces de aguas continentales de la Argentina y consideraciones sobre las áreas ictiológicas de América del Sur. Ecosur, vol. 2, no. 3, p. 1-122.

RINGUELET, R., ARAMBURU, R. and ALONSO De ARAMBURU, A., 1967. Los peces argentinos de agua dulce. La Plata, Argentina : Comisión de Investigación Científica. $602 \mathrm{p}$.

RODRIGUEZ, C., MANCINI, M. and PROSPERI, C., 2005. Use of microalgae to establish the trophyc status of lake La Viña (Argentina). In $10^{\text {th }}$ International Conference on Applied Phycology, Kunming, China .

SCASSO, F., 1999. Peces. In AROCENA, R. and CONDE, D. (Eds.). In Métodos en ecología de aguas continentales con ejemplos de Limnología en Uruguay. Montevideo, Uruguay: DI.R.A.C., Facultad de Ciencias. p. 194-202.

SCHULZ, U. and MARTINS-JUNIOR, H., 2001. Astyanax fasciatus as a bioindicator of water pollution of rio Dos Sinos, RS, Brazil. Braz. J. Biol. = Rev. Bras. Biol., vol. 61, no. 4, p. 615-622.

SERVICIO METEOROLÓGICO NACIONAL, 1992. Estadísticas climatológicas 1981-1990. Serie B-37. Buenos Aires: Fuerza Aérea de Argentina. 709 p.

SILVERIO, M., GROSMAN, F., FRA, E. and SARACHO, M., 2004. Consecuencias ecológicas del florecimiento de una dinofícea en el dique Sumampa (Catamarca). Revista Ciencia y Técnica, vol. 11, p. 1-18.

SMITH, B., 2004. Carp (Cyprinus carpio L.) spawning dynamics and early growth in the lower river Murria, South Australia. Autralia: Adelaide University. 157 p. [Ph.D. Thesis].

SMITH, WS. and BARRELLA, W., 2000. The ichthyofauna of the marginal laggons of the Sorocaba river, SP, Brazil: composition, adundance and effect of the anthropogenic actions. Rev. Brasil. Biol = Braz. J. Biol., vol. 60, no. 4, p. 627-632.

VILLAGRA, A., MOSA, S., REGIDOR, R. and ACUÑA, E., 2005. Monitoreo de la ictiofauna en el embalse El Tunal, Salta, Argentina. In IV Taller Internacional sobre enfoques regionales para el desarrollo y gestión de embalses en la cuenca del Plata. Salto Grande, Argentina-Uruguay. (CD - ROM).

WHITFIELD, AK. and PATERSON, AW., 2003. Distribution patterns of fishes in a freshwater deprived Eastern Cape estuary, with particular emphasis on the geographical headwater region. Water $S A$, vol. 29, no. 1, p. 61-68. 